\title{
CHEMICAL COMPOSITION, ANATOMY, LIGNIN DISTRIBUTION, AND CELL WALL STRUCTURE OF MALAYSIAN PLANT WASTE FIBERS
}

\author{
H. P. S. Abdul Khalil*, M. Siti Alwani, and A. K. Mohd Omar
}

The chemical composition, anatomical characteristics, lignin distribution, and cell wall structure of oil palm frond (OPF), coconut (COIR), pineapple leaf (PALF), and banana stem (BS) fibers were analyzed. The chemical composition of fiber was analyzed according to TAPPI Methods. Light microscopy (LM) and transmission electron microscopy (TEM) were used to observe and determine the cell wall structure and lignin distribution of various agro-waste fibers. The results revealed differences in anatomical characteristics, lignin distributions, and cell wall structure of the different types of fibers investigated. Nevertheless, transmission electron microscopy (TEM) micrographs have confirmed that the well wall structure, in each case, could be described in terms of a classical cell wall structure, consisting of primary $(P)$ and secondary $\left(\mathrm{S}_{1}, \mathrm{~S}_{2}\right.$, and $\left.\mathrm{S}_{3}\right)$ layers.

Keywords: Anatomy; Cell wall structure; Chemical composition; Lignin distribution; Plant fibers

Contact information: School of Industrial Technology, Universiti Sains Malaysia, 11800 Minden, Penang, Malaysia; *Corresponding author : akhalil@usm.my

\section{INTRODUCTION}

Plant waste fibers can be described as lignocellulosics, i.e. resources comprised primarily of cellulose, hemicellulose, and lignin. Lignocellulosics include wood, agricultural residues, water plants, grasses, and other plant substances (Rowell et al. 2000).

Plant waste fibers have the composition, properties, and structure that make them suitable for uses such as composite, textile, and pulp and paper manufacture. In addition, plant fibers can also be used to produce fuel, chemicals, enzymes, and food. Biomass, including agricultural crops and residues, forest resources, and residues, animal and municipal wastes, is the largest source for cellulose in the world. Approximately $2 \times 10^{11}$ tons of lignocellulosics are produced every year, compared with $1.5 \times 10^{8}$ tons of synthetic polymers. Organic plant wastes such as oil palm, pineapple, banana, and coconut fiber are annually renewable, available in abundance, and of limited value at present. These lignocellulosic byproducts could be a principal source for fibers, chemicals, and other industrial products (Reddy and Yang 2005).

In Malaysia, with such a large area of plantation of oil palm (3.87 million ha.), coir (147 thousands ha.), banana (34 thousands ha.), and pineapple (15 thousands ha), large quantities of cellulosic and non-cellulosic raw material are generated during 
harvesting (MAO, 2006; MPOB, 2001). The explosive expansion of plantation in this country has generated enormous amounts of vegetable waste, creating problems in replanting operations and tremendous environmental concerns.

When left on the plantation floor, these waste materials create great environmental problems (Sreekala et al. 1997; Reddy and Yang 2005). Therefore, economic utilization of these fibers will be beneficial. In spite of the abundance of published work dealing with the technological aspects of the agro-fibers applications, the bibliography covering comprehensive fundamental aspects of specific agro-fibers is quite scare, disperse, and inadequate. In order to completely evaluate the potential of agrowastes for new applications, a detailed and comprehensive study of fundamental properties is necessary.

The fundamental aspects considered in the previous literature, with other fibers, have been reported extensively (Balashov et al. 1956; Fengel and Shao 1984; McNeil et al. 1984; Bai et al. 1998; Donaldson 1996), except for oil palm, banana stem, and pineapple leaf fibers. Only the chemical composition and anatomy of these fibers have already been reported (Mansor and Ahmad 1991; Cordeiro et al. 2004; Mishra et al. 2004; John et al. 2005). However, no research has been reported to evaluate the cell-wall structure, lignin distribution, and physical properties of these major plant wastes fibers (oil palm, coir, banana stem, pineapple leaf) in Malaysia until now.

The main objective of the present study is, therefore, to make some observations on the fine structure of plant fibers, using light and electron microscopy. The research findings can lead to a better understanding and knowledge of chemical compositions, fiber dimensions, cell wall structure, and lignin distribution of the fibers. This information is very important to reduce the environmental and health hazards associated with the disposal of plant wastes such as oil palm, banana tree, and pineapple leaf fibers. Hence, this basic studies/knowledge can be used by the food technologist, material scientist, and polymer chemist for further applied research study.

\section{EXPERIMENTAL}

For chemical composition determination, agro-fibers were ground, and 40-mesh fractions were selected. The procedures were performed according to TAPPI Method T $264 \mathrm{om}-88$. The samples were first submitted to Soxhlet extraction with ethanol/benzene $[1: 2(\mathrm{v} / \mathrm{v})]$ for 6 hours. The determination of alpha-cellulose, lignin, and ash content were performed following the standard methods T 212 om-93, T 203 os-74, and T 211 om-93, respectively. Holocelluloses were determined according to a previous study (Wise et al. 1946).

For cell wall structure and lignin distribution determinations, agro fibers were chosen randomly and cut into $2 \times 3 \mathrm{~mm}$ blocks. Samples were then dehydrated in an ethanol series and embedded in Epoxy resin (Epon), which was polymerized for 24 hours at $60^{\circ} \mathrm{C}$. Transverse sections $(1 \mu \mathrm{m})$ were cut from embedded material, using a Sorvall ultra microtome (MT 500) and stained with 1\% Toluidine Blue for lignin distribution determination. The sections were viewed under polarized microscope (Olympus BX50). Ultra-thin sections $(0.1 \mu \mathrm{m})$ also were obtained from embedded samples, stained with $2 \%$ 
uranyl acetate and lead citrate, and finally viewed under transmission electron microscopy (TEM) (Phillips CM12).

\section{RESULTS AND DISCUSSION}

Malaysia is the largest producer of oil palm (Elaeis guineensis Jacq.) (Fig. 1a) in the world. Total planted area of oil palm increased from 73,000, reaching 3.87 million hectares in 2004 (MPOB 2001). Oil palm can reach 18-24 $\mathrm{m}$ in height in nature, but is rarely more than 6 or $9 \mathrm{~m}$ in cultivation. Nowadays, oil palm frond (OPF) contributes $70 \%$ of the overall oil palm industry waste in Malaysia (Eng et al. 2004). It is reported that Malaysia alone produced, during the recent past years, about 30 million tonnes annually of oil-palm biomass, including trunks, fronds, and empty fruit bunches (Abdul Khalil and Rozman 2004).
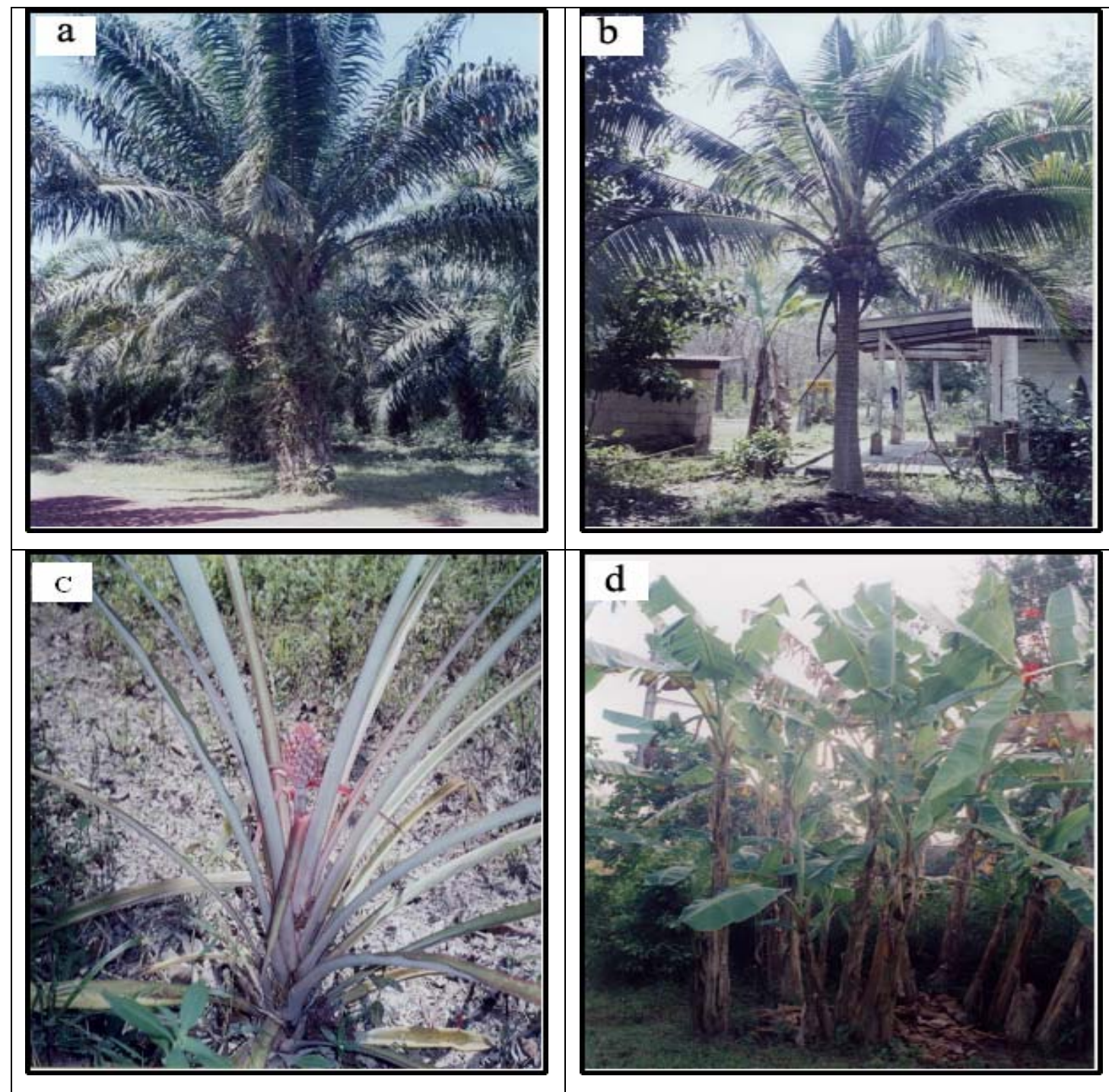

Fig. 1. a) Oil palm b) Coconut c) Pineapple d) Banana. 
Coconut palm (Cocos nucifera L.) (Fig. 1b) is one of the most important crops in Malaysia. Statistics showed that total area planted of coconut palm increased from 117 000 (1998) to 147,000 hectares in 2004 (MAO 2006). Coir fiber is obtained from coconut husk. Coir fiber is one of the hardest natural fibers, because of its high content of lignin.

The pineapple (Ananas comosus) (Fig. 1c) is one of the important tropical fruits in Malaysia, which was produced in economic quantities on about 14,042.9 hectares in 2001 (MAO, 2006). Pineapples are rosette-forming, herbaceous monocots. The stems are short and inconspicuous in the center of the rosette of long and linear leaves.

Bananas (Musaceae) (Fig. 1d) are produced in large quantities in tropical and subtropical areas. The total planted area of banana in Malaysia (2001) was 33,704.2 hectares (MAO, 2006). Banana plants range in height from $0.8 \mathrm{~m}$ to more than $15 \mathrm{~m}$. Each contains a flattened, modified stem, called a pseudostem, consisting of concentric layers of leaf sheath and crown of large leaves (Ennos et al., 2000). After harvesting fruit, the pseudostem is traditionally wasted, as it usually left in the soil plantation to be used as organic materials.

\section{Chemical Composition}

Table 1 shows the percentage of various chemical components present in OPF, COIR, PALF, and BS fiber. The data show that BS fibers exhibited the highest solubility in ethanol-benzene $(10.6 \%)$, compared to other fibers. As for wood processing, higher ethanol-benzene extractive content in BS may be advantageous for decay resistance and will provide good strength in fiber processing, because of its higher specific gravity.

\begin{tabular}{lcccccc}
\hline Table 1. & Chemical composition of different lignocellulosic fibers & \\
\hline & $\begin{array}{c}\text { Oil } \\
\text { palm } \\
\text { frond }\end{array}$ & Coconut & $\begin{array}{c}\text { Pineapple } \\
\text { leaf }\end{array}$ & $\begin{array}{c}\text { Banana } \\
\text { stem }\end{array}$ & Softwood & Hardwood $^{*}$ \\
& 4.5 & 6.4 & 5.5 & 10.6 & $0.2-8.5$ & $0.1-7.7$ \\
\hline Extractive (\%) & 83.5 & 56.3 & 80.5 & 65.2 & $60-80$ & $71-89$ \\
Holocellulose (\%) & 49.8 & 44.2 & 73.4 & 63.9 & $30-60$ & $31-64$ \\
a-cellulose (\%) & 20.5 & 32.8 & 10.5 & 18.6 & $21-37$ & $14-34$ \\
Lignin (\%) & 2.4 & 2.2 & 2.0 & 1.5 & $<1$ & $<1$ \\
Ash (\%) & & & & & & \\
${ }^{*}$ Tsoumis 1996 & & & & & &
\end{tabular}

Generally, coir fibers contained the highest percentage of lignin $(32.8 \%)$, but the lignin content of coir fiber was still lower than that of wood fiber (14-37\%) (Tsoumis 1991). Generally, the high content of lignin in coir fiber made the fiber tougher and stiffer, compared to other fibers. This was because lignin provides plant tissue and individual fibers with compressive strength and stiffens the cell wall of the fibers, to protect the carbohydrates from chemical and physical damage (Saheb and Jog 1999). Lignin is an undesirable polymer, and its removal during pulping requires high amounts of energy and chemicals. PALF fibers had the lowest lignin content, which suggests that this material can undergo bleaching more easily and with the utilization of lower amounts of chemicals than coir fibers. 
Paper strength depends on the cellulose content of raw plant materials. Plant materials with $34 \%$ and over of $\alpha$-cellulose content were characterized as promising for pulp and paper manufacture, from chemical composition point of view (Nieschlag et al., 1960). Cellulose content was also at a satisfactory level (above 40\%) for each type of fiber considered in the present study. PALF fibers contained the highest percentage of $\alpha$ cellulose content (73.4\%), which was higher than wood fiber (30-64\%) (Tsoumis, 1991). The higher cellulose content in pineapple leaf fiber is probably due to the relatively higher weight of the fruit they support and the fact that they are less perishable (Reddy \& Yang, 2005).
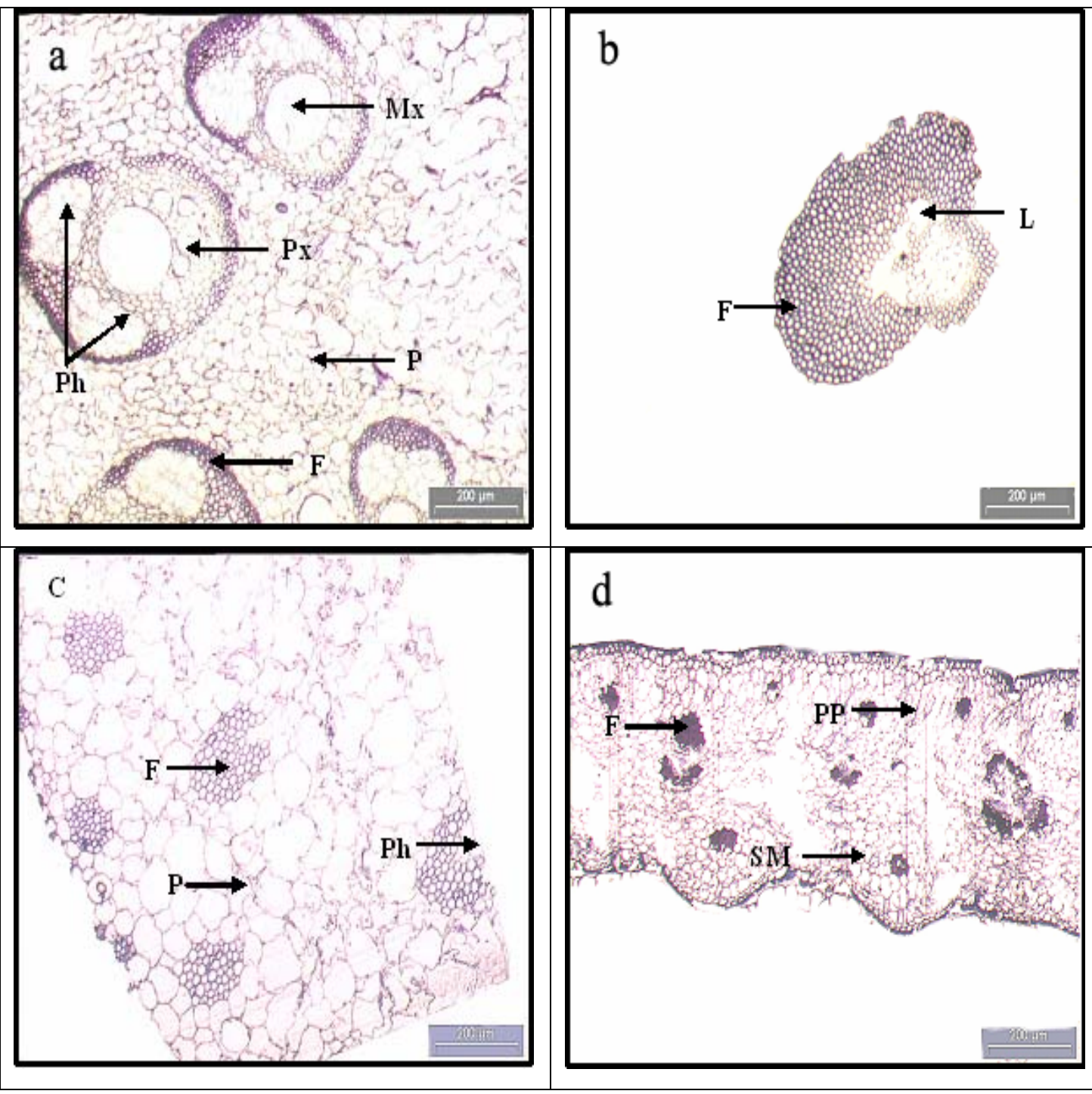

Fig. 2. Transverse section of different types of agro fibers at low magnification (4x). a) Oil palm frond (OPF) b) Coconut (COIR) c) Banana stem (BS) d) Pineapple leaf (PALF). F Fiber; P Parenchyma; Mx Metaxylem; Px Protoxylem; Ph Phloem. F Fiber; L Lacuna; PP Palisade Parenchyma; SM Spongy Mesophyll 


\section{Anatomical Characteristics}

OPF fibers contained various sizes of vascular bundles. The vascular bundles were widely imbedded in thin-walled parenchymatous ground tissue. Each bundle was made up of a fibrous sheath, vessels, fibers, phloem, and parenchymatous tissues (Fig. 2a). Xylem and phloem tissues are clearly distinguishable. Phloem was divided into two separate areas in each bundle. Some vascular bundles also contained several well-defined protoxylem elements. Protoxylem and metaxylem vessels in the bundle were separated by a layer of parenchyma cells (Fig. 3a). According to previous study, within the stem and leaves, proto- and metaxylem vessels are separated by at least one layer of live parenchyma cells, which form a living barrier to possible transfer of gas bubbles between proto- and metaxylem vessels (Tomlinson et al. 2001).
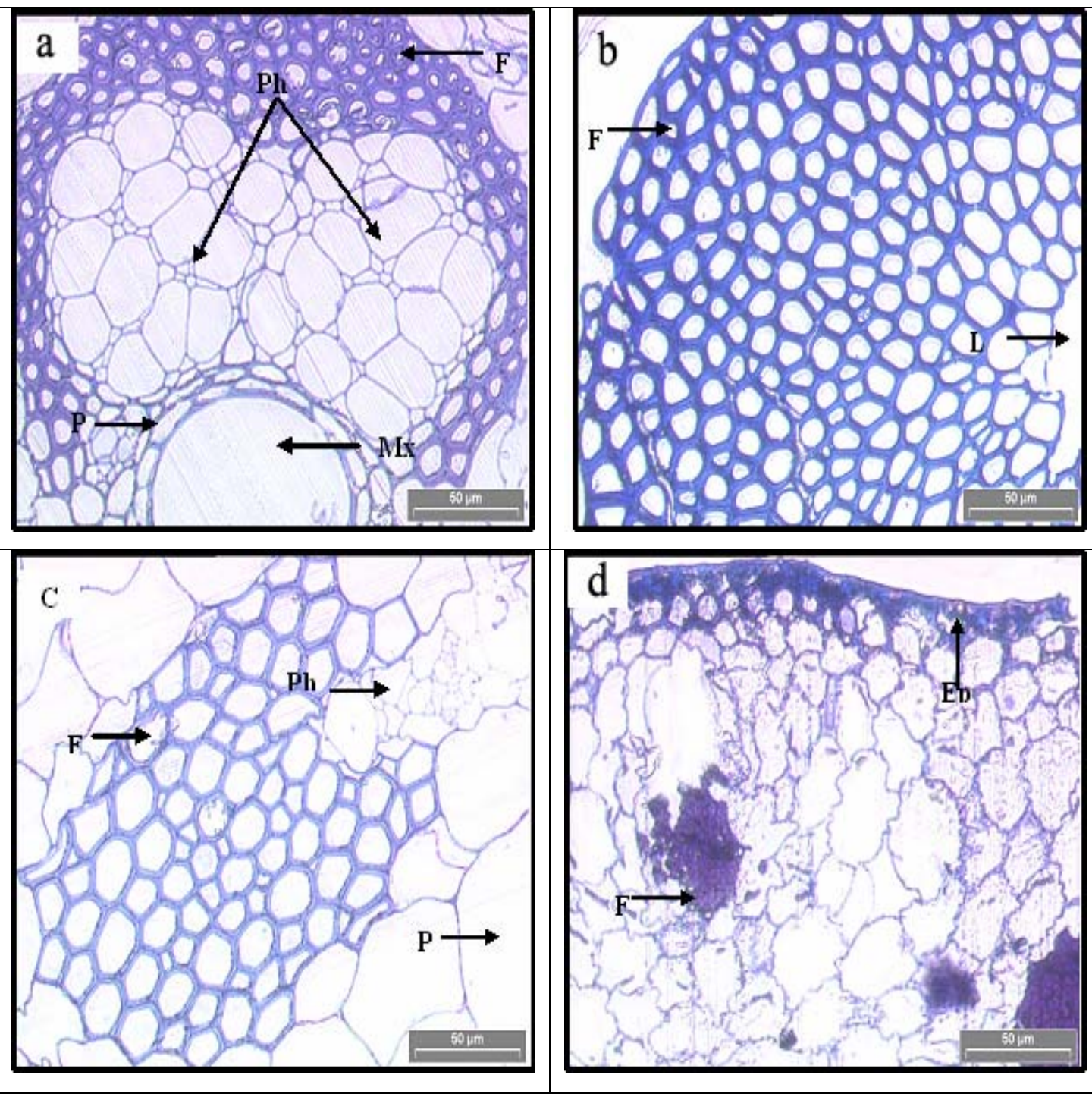

Fig. 3. Transverse section of different types of agro fibers at high magnification (20x). a) Oil palm frond (OPF) b) Coconut (COIR) c) Banana stem (BS) d) Pineapple leaf (PALF). F Fiber; P Parenchyma; Mx Metaxylem; Ph Phloem. F Fiber; L Lacuna; Ep Epidermis 
COIR is a multicellular fiber that consists of fiber, phloem, and parenchyma cells. Unfortunately, from the cross section obtained from the fiber, only fiber and parenchyma fibers can be clearly seen (Fig. 2b). COIR fiber also consists of a central portion, called "lacuna" (Fig. 3b). This porous surface morphology is useful for better mechanical interlocking with the matrix resin for composite fabrication (Sreekala et al. 1997).

The vascular bundles of BS fiber also are widely distributed in parenchymatous ground tissue, which consists only of fiber and phloem, without any other vascular tissues (Fig. 2c and 3c). This situation may occur in certain types of monocot stem. In plant tissue, phloem plays an important role in organic nutrient transport, especially in the case of sugar that is produced during the photosynthesis process (Mauseth, 1988).

Leaf is a primary photosynthesis organ for a plant. Cross-sections of PALF showed that it consists of an epidermis, palisade parenchyma, spongy mesophyll, and fiber bundle (Fig. 2d). Figure 3d shows that the PALF vascular bundle consists only of thick-walled fibers, without other vascular tissues. This situation also may occur in certain species such as orchid and Bromeliad (pineapple). This was one of the adaptations for annual plants, to provide strength and stiffness to the leaf (Mauseth, 1988).

\section{Lignin Distribution}

Qualitative and quantitative determination of lignin distribution has been carried out in several species of agricultural fibers, such as wheat straw, sugarcane, rice plant, poplar and linseed flax (Donaldson 1996; Zhai and Lee 1989; He and Terashima 1991). Unfortunately, there appears to be little information on lignin distribution in monocotyledonous species, especially oil palm, pineapple leaf, and banana stem fibers.

An observation that has been made using an image analyzer illustrated that thickwalled fiber in OPF, COIR, BS, and PALF were strongly lignified after being stained with toluidine blue. The middle lamella showed a high level of lignification for all types of plant fibers (Fig. 4a-4d). Phloem and parenchyma cells in OPF (Fig. 4a) and BS (Fig. 4c) fiber, which consists only of a primary wall, were unlignified, as shown by a weak positive reaction with toluidine blue. Donaldson (1991) also found that lignification in linseed flax was greater in xylem fibers, compared to phloem fibers. In the OPF vascular bundle, fibers were more lignified than metaxylem vessels. Palisade and mesophyll cells, which were thin-walled parenchyma cells, also stained weakly (Fig. 4d). These thin walls are important to absorb sunlight in an optimum manner to be used in the photosynthesis process.

\section{Cell Wall Structure}

The electron microscope provides a unique tool for investigating cell wall ultrastructure. Electron microscopy observations showed that wood cell walls are composed of an intercellular layer, a primary, and a secondary wall. The primary cell wall is a thin layer produced by cell division and the subsequent growth of xylem mother cells, while the secondary wall is a thick layer deposited inside the primary wall. It consists of an outer layer $\left(\mathrm{S}_{1}\right)$, a middle layer $\left(\mathrm{S}_{2}\right)$, and an inner layer $\left(\mathrm{S}_{3}\right)$, each with a different orientation of cellulose microfibrils (Harada \& Cote, 1985). 


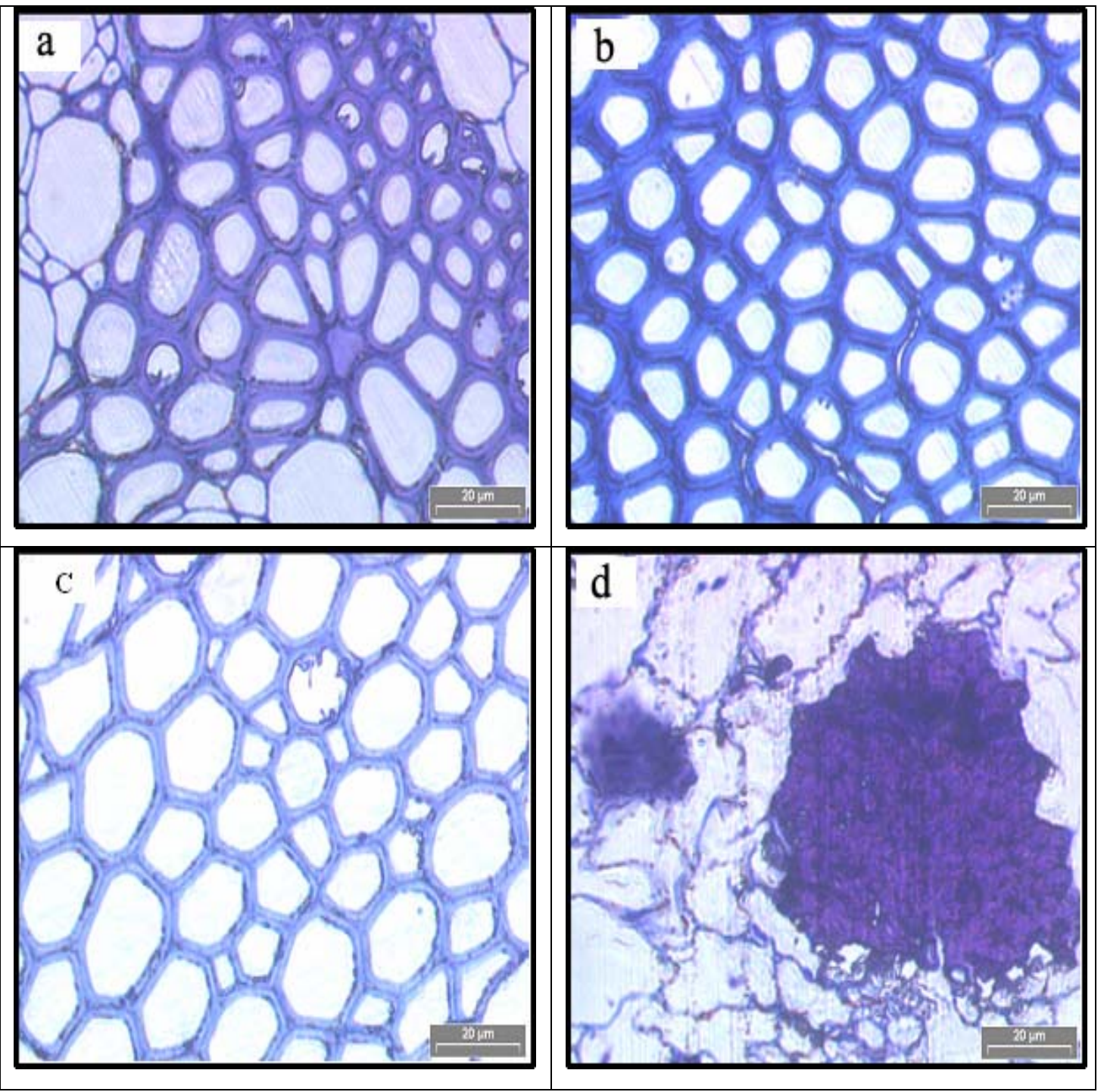

Fig. 4. Transverse section of agro fibers after stained with toluidine blue at high magnification $(40 \times$ ). a) Oil palm frond (OPF) b) Coconut (COIR) c) Banana stem (BS) d) Pineapple leaf (PALF).

Transmission electron microscopy (TEM) views of transverse sections of agro fibers are shown in Figs. 5-6. The electron microscopic observations were restricted mainly to the walls of fibers within the vascular bundles. Generally, all fibers showed great variability in size, shape, and structure of the cell wall (Fig. 5a-5d). The TEM electron micrographs have confirmed that the layered structure of OPF, COIR, PALF, and BS fiber wall contained primary $(\mathrm{P})$ and secondary $\left(\mathrm{S}_{1}, \mathrm{~S}_{2}\right.$ and $\mathrm{S}_{3}$ ) wall layers (Fig. 6a-6d). This structure was similar to the wood cell wall structure that has been proposed by Harada and Cote (1985) and other lignocellulosic fibers such as flax, jute, etc. However, according to Liese (1985), bamboo showed different structure of the cell wall layer. Bamboo culm fiber has a polylamellated wall structure [middle lamella, primary and secondary wall $\left.\left(\mathrm{S}_{0}, \mathrm{~S}_{1-1,1}, \mathrm{~S}_{2-\mathrm{t},} \mathrm{S}_{\mathrm{n}-\mathrm{l}}, \mathrm{S}_{\mathrm{n}-\mathrm{t}}\right)\right]$. A typical tertiary wall is not present, but warts cover the innermost layer of the cell wall. 

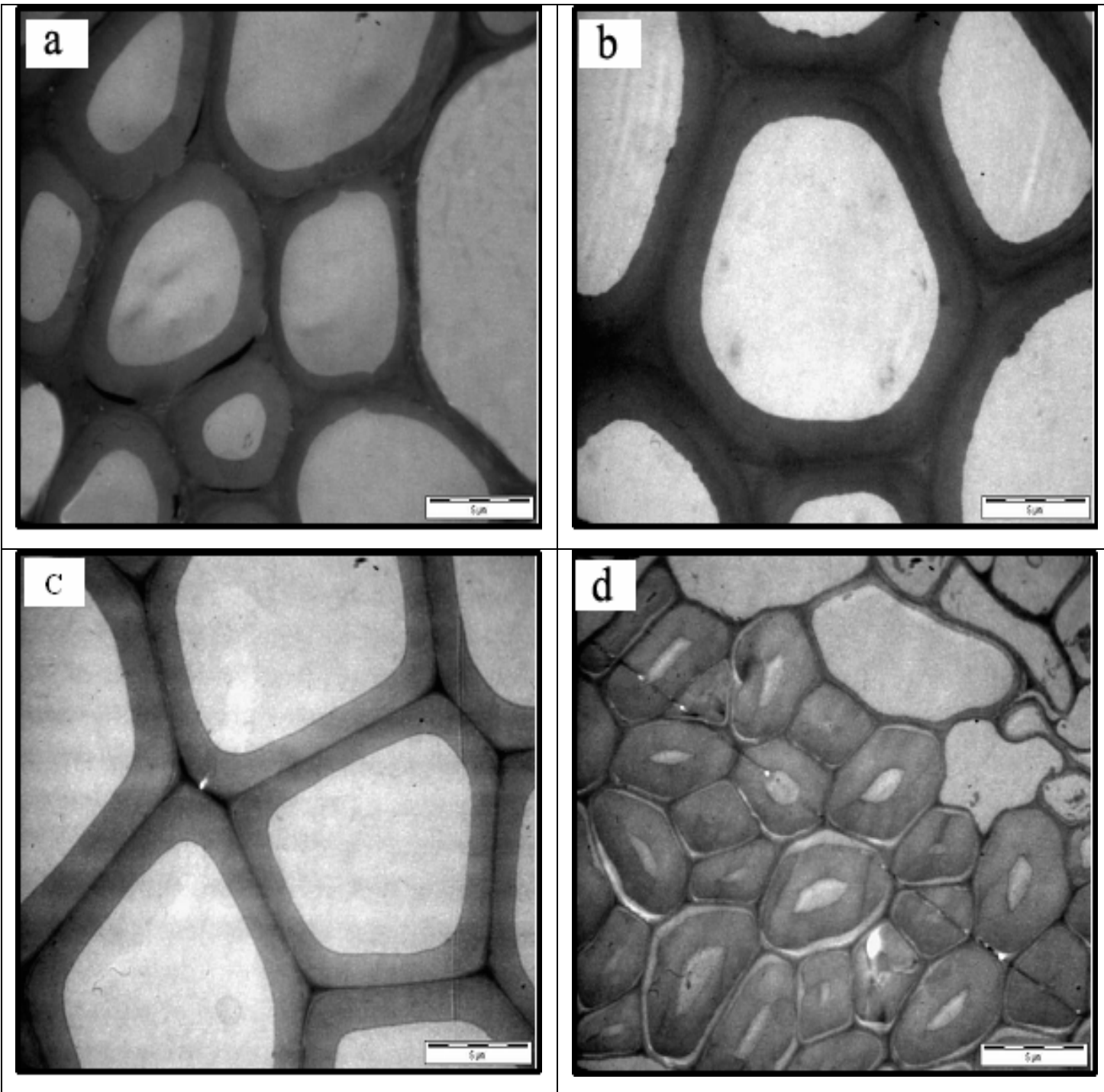

Fig. 5. Transmission electron micrograph of ultrathin section of agro fibers after stained with uranyl acetate and lead citrate at low magnification (3400x). a) Oil palm frond (OPF) b) Coconut (COIR) c) Banana stem (BS) d) Pineapple leaf (PALF).

The various wall layers (primary and secondary wall) clearly appeared in ultrathin transverse sections of fibers. The primary wall appeared as a solid boundary of the cell (Fig. 6a and 6d). The middle lamella, which glues the cells together, showed a clear transition to the adjacent primary wall layers. The dark staining of the middle lamella indicated that it was strongly lignified. The $\mathrm{S}_{1}$ layer of all fibers was well-defined and could be distinguished from the adjoining $\mathrm{S}_{2}$ layer, as it was the brightest layer compared to other layers. Random measurements were taken on high magnification TEM micrographs, and the thickness of the $S_{1}$ layer in agro fibers was found to be in the range of $0.10-0.84 \mu \mathrm{m}$. Total cell wall thickness is largely controlled by the $\mathrm{S}_{2}$ layer. The $\mathrm{S}_{2}$ layer is reinforced by microfibrils that usually lie from 5 to 30 degrees to the axis, and it 
is about forty times thicker than any of the other layers (Booker and Sell, 1998). Cells with thick walls contain a large $S_{2}$ layer, whereas thin-wall cells have a small $S_{2}$ layer. The $\mathrm{S}_{2}$ layer of agro fibers occupied about $43-78 \%$ of the whole wall in thickness, and BS fibers exhibited the thickest $\mathrm{S}_{2}$ layer $(1.57 \mu \mathrm{m})$ (Fig. 6c).
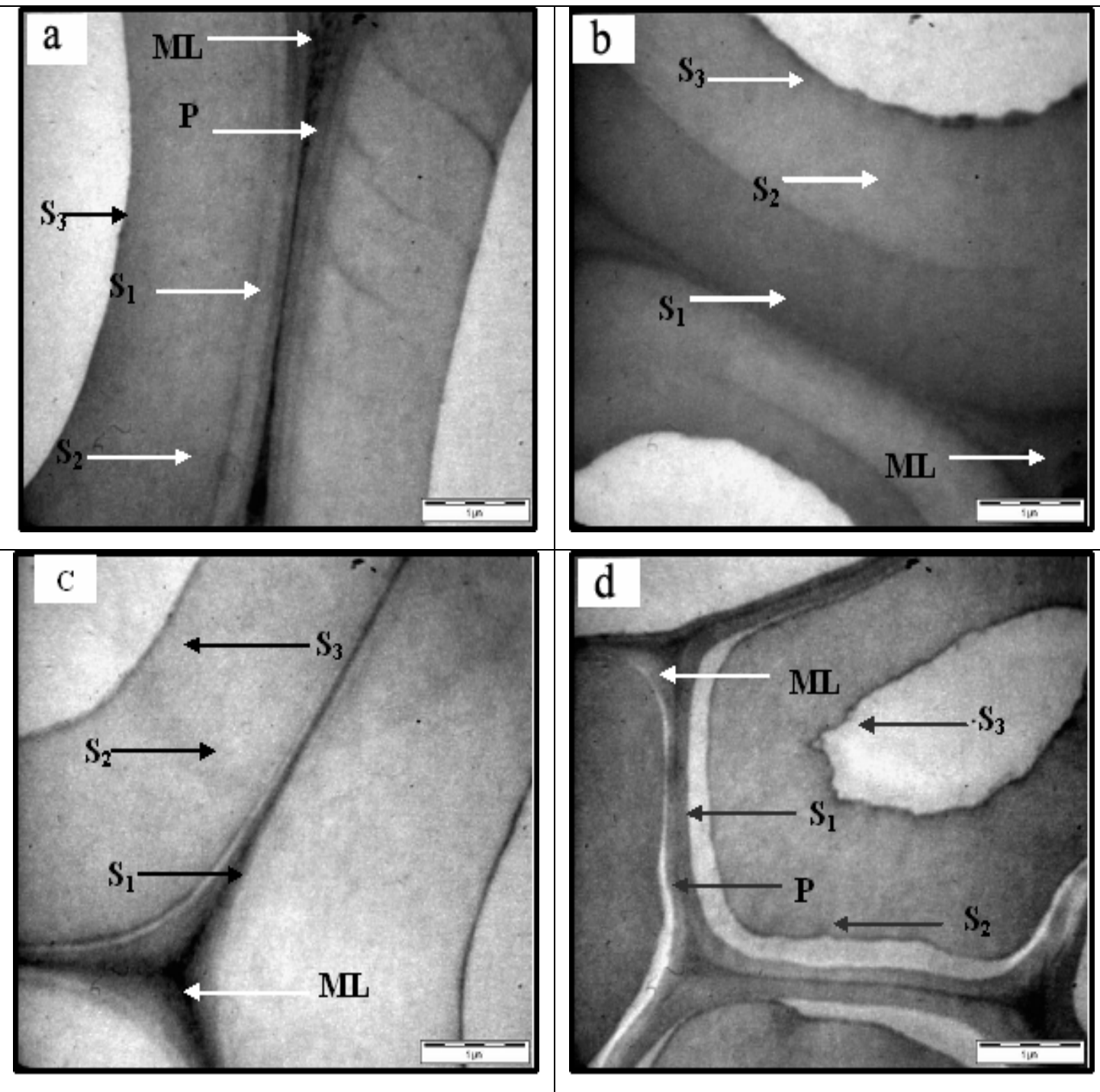

Fig. 6. Transverse section of a multi-layered structure of agro fibers at high magnification (17000x). a) Oil palm frond (OPF) b) Coconut (COIR) c) Banana stem (BS) d) Pineapple leaf (PALF). ML Middle Lamella; $P$ Primary Wall; $S_{1} S_{2} \& S_{3}$ Secondary wall sub-layers

The observations using TEM micrographs also provide evidence for the presence of a distinct $\mathrm{S}_{3}$ layer in the cell wall of agro fibers. Agro fibers showed a great variability in the thickness of the $\mathrm{S}_{3}$ layer. COIR fibers (Fig. 6b) contained a well developed $\mathrm{S}_{3}$ layer, being the thickest $S_{3}$ layers $(0.089 \mu \mathrm{m})$ among all fibers. COIR fibers are supposed to have more resistance against collapse due to water tension and buckling due to axial compression forces, as also proposed by Booker and Sell (1998). Previous studies have 
reported that $P$. radiata earlywood tracheids also showed great deal of variability in the thickness of the $S_{3}$ layer, both within and between tracheids $(0.06-0.3 \mu \mathrm{m})$. It has been suggested that the irregular thickness might be better suited to relieve the pressure of the axial compression force on the tracheid wall than one of uniform thickness (Singh et al., 2002).

\section{CONCLUSIONS}

The above studies can be summarized as follows:

i) In general, the chemical composition of oil palm fibers followed the order given below:

$$
\begin{aligned}
& \text { Lignin: (highest) COIR }>\text { OPF }>\text { BS }>\text { PALF } \text { (lowest); } \\
& \alpha \text {-cellulose: (highest) PALF }>\text { BS }>\text { OPF }>\text { COIR (lowest); } \\
& \text { Holocellulose: (highest) OPF }>\text { PALF }>\text { BS }>\text { COIR (lowest); } \\
& \text { Extractive: (highest) BS }>\text { COIR }>\text { PALF }>\text { OPF (lowest); } \\
& \text { Ash: (highest) OPF }>\text { COIR }>\text { PALF }>\text { BS (lowest). }
\end{aligned}
$$

ii) Determinations of lignin distribution in oil palm fibers revealed evidence of lignification in most of the fiber and vessel (meta- and protoxylem) material, except for the phloem. Most of the fibers showed positive staining with toluidine blue. The middle lamella showed a high level of lignification for all types of fibers.

iii) Transmission electron microscopy (TEM) micrographs have confirmed that cell wall structure of all types of agro fibers (OPF, COIR, PALF and BS) consist of primary $(\mathrm{P})$ and secondary $\left(\mathrm{S}_{1}, \mathrm{~S}_{2}\right.$ and $\left.\mathrm{S}_{3}\right)$ layers.

\section{ACKNOWLEDGMENTS}

The authors would like to thank Ministry of Science, Technology and Innovation (MOSTI) for providing the research grant (Science Fund RM 9) and Universiti Sains Malaysia, that has made this research work possible.

\section{REFERENCES CITED}

Abdul Khalil, H. P. S., and Rozman, H. D. (2004). Gentian dan Komposit Lignoselulosik. Universiti Sains Malaysia Publisher, Malaysia.

Balashov, V., Preston, R. D., Ripley, G. W., and Spark, L. C. (1956). "Structure and mechanical properties of vegetable fibres. I. The influence of strain on the orientation of cellulose microfibrils in sisals leaf fibre," Proc. Roy. Soc. B. 146, 460-468.

Bai, S. L., Li, R. K. Y., Wu, L. C. M., Zheng, H. M., and Mai, Y. W. (1998). "Tensile failure mechanisms of sisal fibers in composites," J. Materials Science Letters 17 (21), 1805-1807. 
Booker, R. E., and Sell, J., (1998). "The nanostructure of the cell wall of softwoods and its function in a living tree," Holz Roh-Werstoff 56, 1-8.

Cordeiro, N., Belgacem, M. N., Torres, I. C., and Moura, J. C. V. P. (2004). "Chemical composition and pulping of banana pseudo-stem," Industrial Crops and Products. 19, 147-154.

Donaldson, L. A. (1996). "Determination of lignin distribution in agricultural fibres," Wood Processing Division, New Zealand Forest Research Institute. 4418, 1-25.

Eng, K. T., Ooi, K. I., Rosma, A., and Mohd Azemi, M. H. (2004). "Potential of oil palm fronds (OPF) as cultivation media for yeast growth," In: Proceedings of $3^{\text {rd }}$ USMJIRCAS Joint International Symposium: Lignocellulose: Materials for the Future from the Tropics, Cheng, L. H. \& Tanaka, R. (eds.). Penang, Malaysia: Universiti Sains Malaysia, 134-138.

Ennos, A. R., Spatz, H-Ch., and Speck, T. (2000). "The functional morphology of the petioles of the banana, Musa textiles," J. Experimental Botany 51 (353), 2085-2093.

Fengel, D., and Shao, X. (1984). "A chemical and ultrastructural study of the bamboo species Phyllostachys makinoi Hay," Wood Sci. Technol. 18, 103-112.

Harada, H., and Cote, W. A. (1985). "Structure of wood,". In: Biosynthesis and Biodegradation of Wood Components, Higuchi (ed), Academic Press, Orlando, 1-4.

He, L., and Terashima, N. (1991). "Formation and structure of lignin in monocotyledons IV. Deposition process and structural diversity of lignin in the cell wall of sugarcane and rice plant studied by ultraviolet microscopic spectroscopy," Holzforschung 45, 191-198.

John, V. M., Cincotto, M. A., Sjöström, C., Agopyan, V., and Oliveira, C.T.A. (2005). "Durability of slag mortar reinforced with coconut fibre," Cement Concrete Composites 27, 565-574.

Liese, W. (1985). "Anatomy and properties of bamboo," In: Proceedings of the International Bamboo Workshop, Hangzhou, China, 196-208.

MAO (Ministry of Agriculture) Hectareage of Industrial Crops by Types, Malaysia (2006) [Online]. [Accessed 18 January 2006]. Available from World Wide Web: http://www.doa.gov.my/doa/main.php?Content=articles\&ArticleID $=5$

Malaysian Palm Oil Board (MPOB). (2001) Oil Palm Statistics, 21, 131.

Mansor, H., and Ahmad, A. R. (1991). "Chemical composition of the oil palm trunk," Proc. Seminar Oil Palm Trunk \& Other Palmwood Utilization, PORIM, Kuala Lumpur, 335-342,

Mauseth, J. D. (1988). Plant Anatomy. The Benjamin/Cummings Publishing Company Inc. 1988

McNeil, M., Darvill A.G., Fry, S.C., and Albershiem, P. (1984). "Structure and function of the primary cell walls of plants," Ann. Rev. Plant Physiol. 53, 625-663.

Mishra, S., Mohanty, A. K., Drzal, L. T., Misra, M., and Hinrichsen, G. (2004). "A review on pineapple leaf fibers, sisal fibers and their biocomposites," Macromol. Mater. Eng., 289, 955-974.

Nieschlag, H. J., Nelson, G. H., Wolff, J. A., and Perdue, R. E. (1960). “A search for new fiber crops," Tappi, 43 (3), 193-194.

Reddy, N., and Yang, Y. (2005). "Biofibers from agricultural by products for industrial applications," TRENDS in Biotechnology 23 (1), 22-27. 
Rowell, R. M., Han, J. S. and Rowell, J. S. (2000). "Characterization and factors effecting fiber properties," Natural Polymers and Agrofibers Composites. Preparation, Properties and Applications, F. Elisabete, L. L. Alcides, and H. C. Mattoso (eds.), Emrapa Instrumentacao Agropecuaria, Brasil, 115-134.

Saheb, N. D., and Jog, J. P. (1999). "Natural fiber polymer composites: A review," Adv. Polym. Tech. 18, 351-363.

Singh, A., Daniel, G., and Nilsson, T. (2002). "High variability in the thickness of the S3 layer in Pinus radiata tracheids," Holzforschung 56: 111-116.

Sreekala, M. S., Kumaran, M. G., and Thomas, S. (1997). “Oil palm fibers: Morphology, chemical composition, surface modification and mechanical properties," J. Applied Polymer Sci. 66, 821-835.

TAPPI (Technical Association of the Pulp and Paper Industry) Test Methods. TAPPI Press, Atlanta, Georgia. 1994.

Tomlinson, P. B., Fisher, J. B., Spangler, R. E., and Richer, R. A. (2001). "Stem vascular architecture in the rattan palm Calamus (Arecaceae-Cal-amoideae-Calaminae)," Amer. J. Botany 88, 797-809.

Tsoumis, G. (1991). Science and technology of wood: structure, properties and utilization, Van Nostrand Reinhold, New York.

Wise, L. E., Murphy, M, and D'Addieco, A. A. (1946). "Chlorite holocellulose: Its fractionation and bearing on summative wood analysis and on studies on the hemicelluloses," Paper Trade J. 122 (2), 35-43.

Zhai, H. M., and Lee, Z. Z. (1989). "Ultrastructure of delignification in alkaline pulping of wheat straw," J. Wood Chemistry Technology 9, 387-406.

Article submitted: August 22, 2006; First review set completed: October 8, 2006; Revised version accepted: November 2, 2006; Published: November 4, 2006. 